\title{
Aceitação sensorial de híbridos de milho doce e híbridos de milho verde em intervalos de colheita ${ }^{1}$
}

\author{
Jéssica da Silva Camilo², Vitor Hugo Barbosa Barbieri, Ramon Macedo Rangel ${ }^{4}$, Deborah Santesso Bonnas ${ }^{5}$, \\ José Magno Queiróz Luz ${ }^{6}$, Roberta Camargos de Oliveira*7 \\ http://dx.doi.org/10.1590/0034-737X201562010001
}

\section{RESUMO}

A composição química e a textura dos grãos do milho doce estão, diretamente, relacionadas com as classes de endosperma que interferem na aceitação do produto pelos consumidores. Por isso, este trabalho teve por objetivo avaliar as características sensoriais de híbridos de milho doce e de híbridos de milho verde, em função de intervalos de colheita. O experimento foi instalado na Estação Experimental de Pesquisa da Syngenta Seeds Ltda, no município de Uberlândia-MG. O delineamento experimental foi de blocos casualizados, em esquema fatorial 8x4, correspondente a oito híbridos (seis híbridos experimentais de milho doce - SWC03, SWC04, SWC05, SWC06, SWC07 e SWC08 e dois híbridos de milho verde SWC01 e SWC02) e quatro intervalos de colheita (26, 28, 30 e 32 dias após a colheita-DAF), com três repetições. No estudo, que envolveu 41 pessoas (25 mulheres e 16 homens), utilizando-se o teste de aceitação com escala hedônica, concluiu-se que os híbridos de milho doce têm maior aceitação que os híbridos de milho verde, independentemente do intervalo de colheita. Colheitas tardias (32 DAF) refletem-se em redução da aceitabilidade do milho doce, que se assemelha à do milho verde (entre indiferente e gostei ligeiramente, para cor, e desgostei ligeiramente e desgostei moderadamente, para textura e sabor). Para todos os híbridos testados, a colheita, quando realizada entre 26 e 28 DAF, proporciona produtos com melhores resultados sensoriais (textura, sabor e cor).

Palavras-chave: Zea mays subsp. saccharata., composição dos grãos, qualidade industrial.

\section{ABSTRACT}

\section{Sensory acceptance of hybrids of sweet corn and hybrids of green corn in harvest intervals}

The chemical composition and texture of the grains of sweet corn are directly related to the classes of endosperm that interfere in the product acceptance by the consumers. Thus, the objective of the present study was to evaluate the sensory characteristics of hybrids of sweet and green corn according to harvest intervals. The experiment was conducted at the Experimental Research Station of Syngenta Seeds Ltda, in the city of Uberlândia, State of MG. The experimental design was a randomized block in an 8 x 4 factorial design, corresponding to eight hybrids (six hybrids of sweet corn: SWC03, SWC04, SWC05, SWC06, SWC07 and SWC08, and two hybrids of green corn: SWC01 and SWC02) and four harvest intervals (26, 28, 30 and 32 days after harvest- DAH), with three replications. In the study, which involved 41 people (25 women and 16 men), using the acceptance test with hedonic scale, it was concluded that hybrids of sweet corn have greater acceptance than hybrid of green corn, regardless of harvest

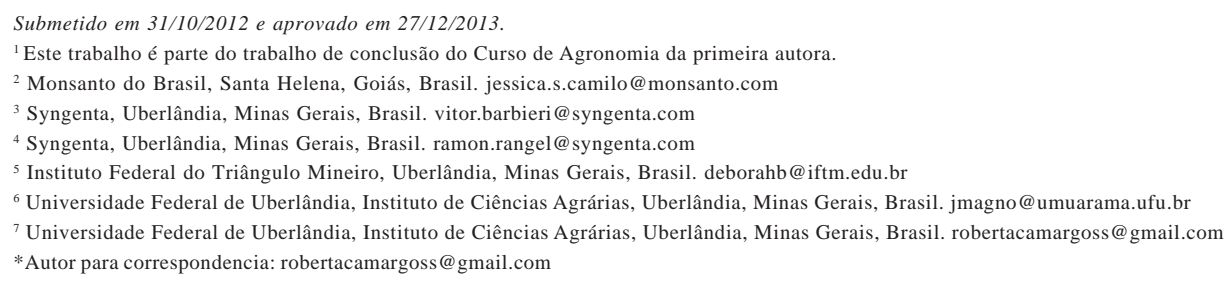


interval. A late harvest (32 DAF) reflects in a reduction in the acceptability of sweet corn, which resembles to the acceptance of green corn (between indifferent and slightly liked it for color and, slightly disliked it and moderately liked it for texture and flavor). In all the tested hybrids, when the harvest was performed between 26 and 28 DAH, products with better sensory results (texture, flavor and color) were provided.

Key words: grain composition, industrial quality, Zea mays subsp. saccharata.

\section{INTRODUÇÃO}

Em países tropicais, o cultivo de milho doce (Zea mays subsp. saccharata) é relativamente recente. O Brasil destina cerca de 36 mil hectares ao plantio dessa cultura, o que representa apenas $14,4 \%$ da área ocupada pelo milho doce dos Estados Unidos. A produção é específica para o consumo humano e dentre as diversas possibilidades de uso alimentar, destacam-se os enlatados (processamento industrial) e a forma in natura (Oliveira Junior et al., 2006).

O milho doce difere do milho normal pelos teores de açúcares e de amido presentes no endosperma (Aragão, 2002), sendo a composição química o fator que interfere diretamente no sabor e na textura dos grãos, o que está relacionado com as classes de endosperma (Tracy, 2001). O milho verde é o milho colhido e consumido ainda fresco, enquanto os grãos estiverem macios (70 a $80 \%$ de umidade) e antes da total conversão do açúcar em amido (Courter et al.,1988). Produtores consideram o milho verde como fonte adicional de renda, pois apresenta valor comercial superior ao do milho comercializado na forma de grãos (Caniato et al., 2004).

Considerando-se o mercado do milho in natura, as características sensoriais de aparência, como cor, sabor e textura, devem ser tratadas com relevância. Portanto, a análise sensorial, a qual mensura os atributos de um dado produto por meio dos sentidos, aponta a qualidade do milho doce (Kwiatkowski \& Clemente, 2007) e milho verde.

Os programas de melhoramento genético de milho doce de empresas privadas, além de atender às exigências quanto a produtividade, resistência a doenças e requisitos impostos pelas indústrias de processamento, também se preocupam com a aprovação dos consumidores (Barbieri et al., 2006), pois aparência e sabor refletemse na aceitação e na preferência, consolidando a potencialidade dos materiais e direcionando a tomada de decisão de melhoristas (Oliveira Junior, et al., 2006).

Ademais, a avaliação de genótipos (adaptação às regiões e manejo) e a preferência dos consumidores são imprescindíveis para diversificar os cultivares utilizados pelos produtores e melhorar a qualidade do produto (Grigulo et al., 2011).
Segundo Dutcosky (1996), é importante a realização de uma análise sensorial determinante, que permita conhecer os vários aspectos exigidos pelos consumidores ao escolher um alimento. Além de atuar como instrumento de garantia de qualidade do resultado final do produto, é capaz de detectar peculiaridades que não podem ser percebidas por outros instrumentos, ou seja, revela a individualidade existente para a preferência de certos sabores, aromas, cores, luzes, formas, sendo que essas variações podem ser reforçadas pela personalidade, educação, bem como pela estrutura cultural e pelo nível social.

Recomenda-se a colheita dos milhos doce e verde quando os grãos contêm de 72 a $78 \%$ de umidade (estádio leitoso), o que ocorre entre 20 a 28 dias após o florescimento (DAF). O avanço da maturação dos grãos faz com que a maioria do açúcar seja convertido em amido, reduzindo-se o sabor adocicado e a maciez (Parentoni et al., 1990).

Apesar do crescimento gradual, nos últimos anos, do segmento de cultivo para consumo in natura, são poucas as informações sobre a disponibilidade de novos cultivares e híbridos e o período ideal de colheita, o qual interfere na composição dos grãos e, por conseguinte, na aceitação pelos consumidores.

Por essa razão, este trabalho teve por objetivo avaliar a aceitação dos consumidores, segundo as características sensoriais de híbridos de milho doce e de milho verde, em diferentes intervalos de colheita.

\section{MATERIAL E MÉTODOS}

O experimento foi realizado na Estação Experimental de Pesquisa da Syngenta Seeds Ltda, no município de Uberlândia-MG, entre 12 de dezembro de 2009 e 20 de março de 2010.

Foram avaliados seis híbridos simples experimentais de milho doce (SWC03, SWC04, SWC05, SWC06, SWC07 e SWC08) e dois híbridos de milho verde (SWC01 e SWC02). A semeadura dos híbridos foi realizada mecanicamente, com o espaçamento de $60 \mathrm{~cm}$ entre linhas. No estádio fenológico V5, procedeu-se ao desbaste, ajustando-se o número de plantas para o estande final de 55 mil plantas ha-1. 
O delineamento experimental foi de blocos casualizados (DBC), em esquema fatorial 8x4, correspondente a híbridos (SWC01, SWC02, SWC03, SWC04, SWC05, SWC06, SWC07 e SWC08) e dia de colheita $(26,28$, 30 e 32 dias após o florescimento - DAF), totalizandose 32 tratamentos, com três repetições. Cada parcela foi constituída por quatro linhas de 4,0 m de comprimento, sendo a parcela útil as duas linhas centrais $\left(7,2 \mathrm{~m}^{2}\right)$.

De acordo com os resultados da análise química do solo, efetuou-se a adubação de semeadura com o formulado 08-20-20, na dose de $750 \mathrm{~kg} \mathrm{ha}^{-1}$, e duas coberturas com 20-00-20 (500 kg ha-1), entre V3 e V6. O controle de pragas e de plantas infestantes foi realizado com pulverizações de inseticidas e herbicidas, respectivamente, registrados para a cultura e em doses recomendadas pelo fabricante. Não foi realizado o controle químico de doenças, uma vez que era objetivo do programa de melhoramento fazer avaliação de doenças nos híbridos experimentais.

Para a determinação do ponto de colheita das espigas, foi realizado o monitoramento do florescimento feminino, o qual correspondeu ao dia em que $50 \%$ das plantas da parcela útil emitiram pelo menos $1 \mathrm{~cm}$ de estigma visível acima da ponta da espiga. A partir da data de florescimento, realizou-se a colheita manual das espigas das duas linhas centrais de cada parcela, aos 26, 28, 30 e 32 dias após o florescimento - DAF, sempre no período da manhã.

Para a realização da análise sensorial, foram colhidas amostras simples, com dez espigas de cada uma das três repetições de cada tratamento e, em seguida, essas amostras simples foram homogeneizadas, para a retirada de uma amostra composta, contendo aproximadamente 20 espigas, que foi acondicionada em saco plástico devidamente identificado com etiqueta e encaminhado, logo após, ao Laboratório de Análise Sensorial do Instituto Federal de Educação, Ciência e Tecnologia do Triângulo Mineiro IFET, em Uberlândia. Este procedimento foi realizado para os 32 tratamentos.

No Laboratório de Análise Sensorial do IFET de Uberlândia, as espigas de cada amostra foram despalhadas e devidamente higienizadas. Em seguida, cortaram-se as espigas em três pedaços iguais, retirando-se as pontas, e estes foram cozidos por 15 minutos em água. As amostras foram apresentadas aos participantes em pratos plásticos brancos, em temperatura ambiente, codificadas com números de três dígitos. Os consumidores utilizaram água à temperatura ambiente, para lavar o palato entre uma amostra e outra.

As amostras foram avaliadas, utilizando-se o Teste de Aceitação. Participaram deste estudo 41 consumidores (nesse teste é recomendado um número de 50 a 100) do produto, sendo 25 mulheres e 16 homens. A ordem de apresentação das amostras foi balanceada e seguiu o delineamento inteiramente casualizado (DIC), em esque- ma fatorial 8x4, correspondente aos híbridos (SWC01, SWC02, SWC03, SWC04, SWC05, SWC06, SWC07 e SWC08) e dia de colheita $(26,28,30$ e 32 dias após o florescimento - DAF), totalizando-se 32 tratamentos, com 41 repetições (provadores). As amostras foram apresentadas monadicamente (três sessões), aos participantes, e, estes, relataram a intensidade de satisfação com os materiais (hibridos). Foi utilizada uma ficha com escala hedônica de nove pontos (9-gostei extremamente, 8-gostei muito, 7-gostei moderadamente, 6-gostei ligeiramente, 5-indiferente, 4-desgostei ligeiramente, 3-desgostei moderadamente, 2-desgostei muito, 1-desgostei extremamente), para avaliar o quanto cada participante gostou do sabor, da cor e da textura dos híbridos.

Os dados foram submetidos à análise de variância, pelo teste $\mathrm{F}$, e as médias do fator qualitativo (híbrido) foram comparadas pelo teste de Tukey a $5 \%$ de significância. Para o fator quantitativo (intervalo de colheita após o florescimento) foram feitas regressões polinomiais com o programa SISVAR (Ferreira, 2008).

\section{RESULTADOS E DISCUSSÃO}

Os híbridos testados neste trabalho apresentaram melhores ajustes ao modelo quadrático de regressão para textura, sabor e cor (Figuras 1, 2 e 3). A partir dos gráficos na Figura 1, foi possível observar que, à medida que a colheita foi realizada mais tardiamente, a média de aceitação de sabor decresceu. A aceitação foi variável, de acordo com a composição química dos materiais (sabor), em todos os híbridos, e os valores máximos relacionaram-se às colheitas realizadas entre 26 e 28 dias após o florescimento.

A maior média de aceitação quanto ao sabor foi dada ao híbrido de milho doce SWC05 (7,57; relacionado entre gostei moderadamente e gostei muito). Os híbridos de milho doce SWC03, SWC06, SWC07 e SWC08 tiveram boa aceitação, com atribuições entre gostei ligeiramente e gostei moderadamente. Já para os híbridos de milho verde SWC01, SWC02, a média entre os participantes revelou desgosto ligeiro a indiferença.

Em todos os períodos de colheita, os híbridos de milho verde (SWC01 e SWC02) tiveram menor aceitação que os híbridos de milho doce, quanto ao sabor e textura (Figura 1 e 2- gráficos de barra), com conotações entre desgosto ligeiro a moderado. Os híbridos de milho doce (SWC03 a SWC 08) não diferiram entre si, significativamente, quando colhidos aos 26 e 28 DAF, com opiniões entre gostei ligeiramente a gostei moderadamente. Este resultado mostra a grande aceitação, por parte do consumidor, do milho doce in natura.

O milho da classe superdoce tem duas vantagens sobre o milho verde. A primeira é que ele é de duas a três 
vezes mais doce; a segunda é que sua transformação de açúcar em amido é praticamente desprezível. Assim este tipo de milho superdoce pode permanecer doce até dez dias após a colheita (Tracy, 2001).

No período subsequente à maturação fisiológica, os grãos de milho doce perdem umidade mais lentamente que os grãos de milho normal, em consequência do me- tabolismo diferenciado e da grande proporção de água, em relação à matéria seca, durante os estádios anteriores à maturação fisiológica (Reis, 2009). Esse fator também se relaciona com a maior aceitação pelos consumidores, visto que a preferência é por grãos macios.

$\mathrm{Na}$ colheita realizada aos $30 \mathrm{DAF}$, houve pequena interferência na aceitação, passando a prevalecer a in-
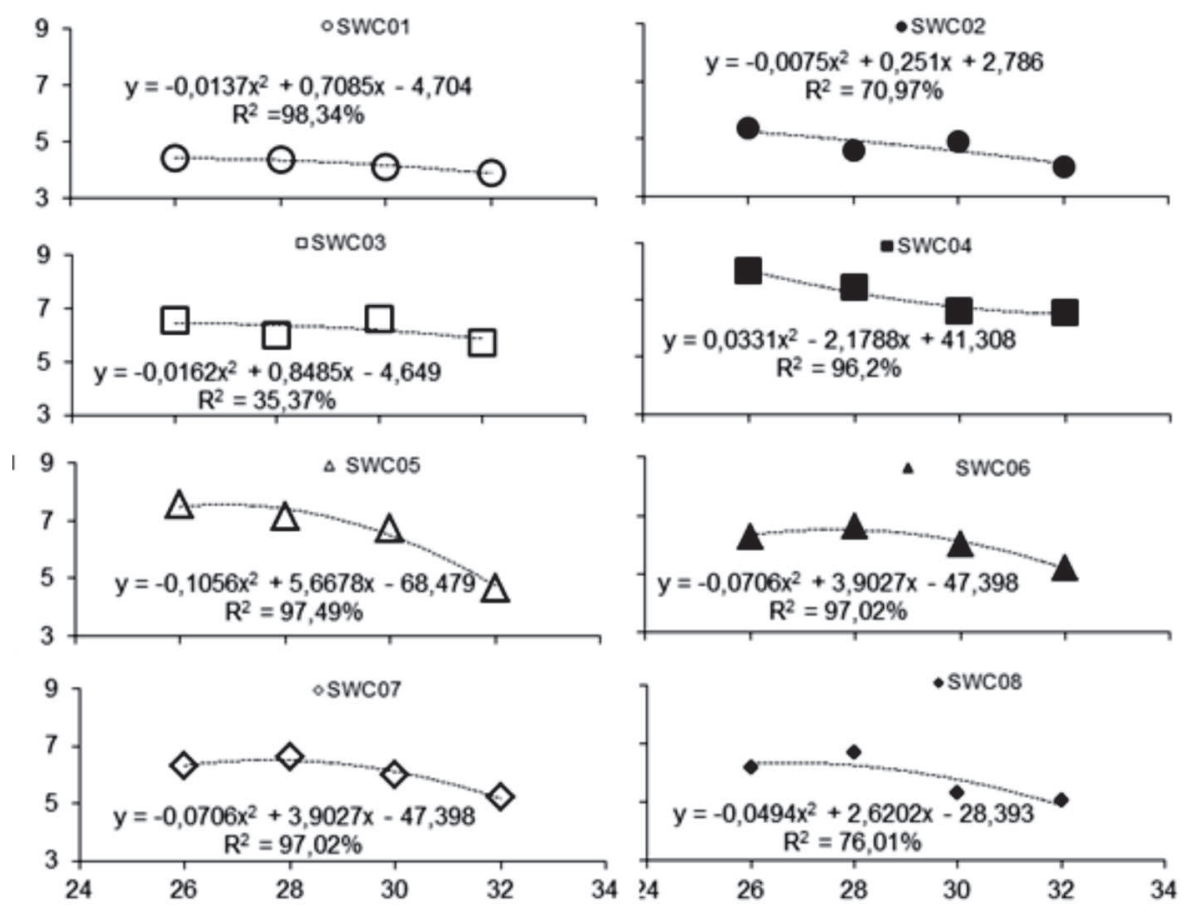

Dias após florescimento

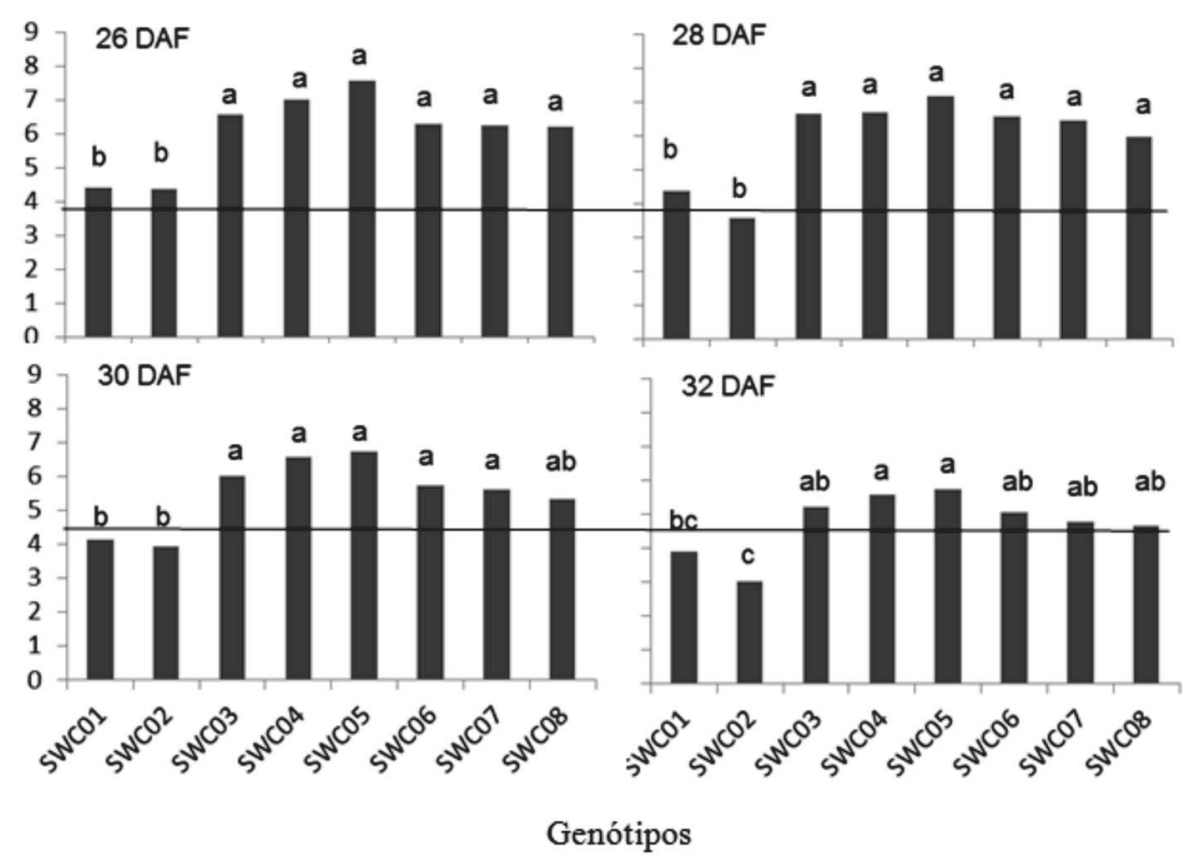

*avaliada em escala hedônica variando de 1:' desgostei extremamente' a 9:'gostei extremamente'

**Médias seguidas por letras iguais não apresentam diferenças significativas pelo teste de Tukey, a 5\% de significância.

Figura 1. Média de aceitação quanto ao sabor de híbridos de milho doce em função de intervalos de colheita. UFU, Uberlândia, 2010. 
diferença a gostei ligeiramente. Este fato, possivelmente, relaciona-se com as alterações que ocorrem no metabolismo, no decorrer do processo de maturação natural. A velocidade das atividades no interior dos grãos é variável com o material genético. Neste experimento, observou-se que o híbrido de milho doce SWC08, aos $30 \mathrm{DAF}$, apesar de não diferir dos demais hibridos de milho doce, também teve média que não se diferenciou daquela dos híbridos de milho verde (com menor aceitação); logo, provavelmente, as alterações que depreciam o sabor e a textura ocorreram de forma mais intensa neste híbrido, aproximando-o das notas relacionadas com materiais com características menos agradáveis ao paladar.
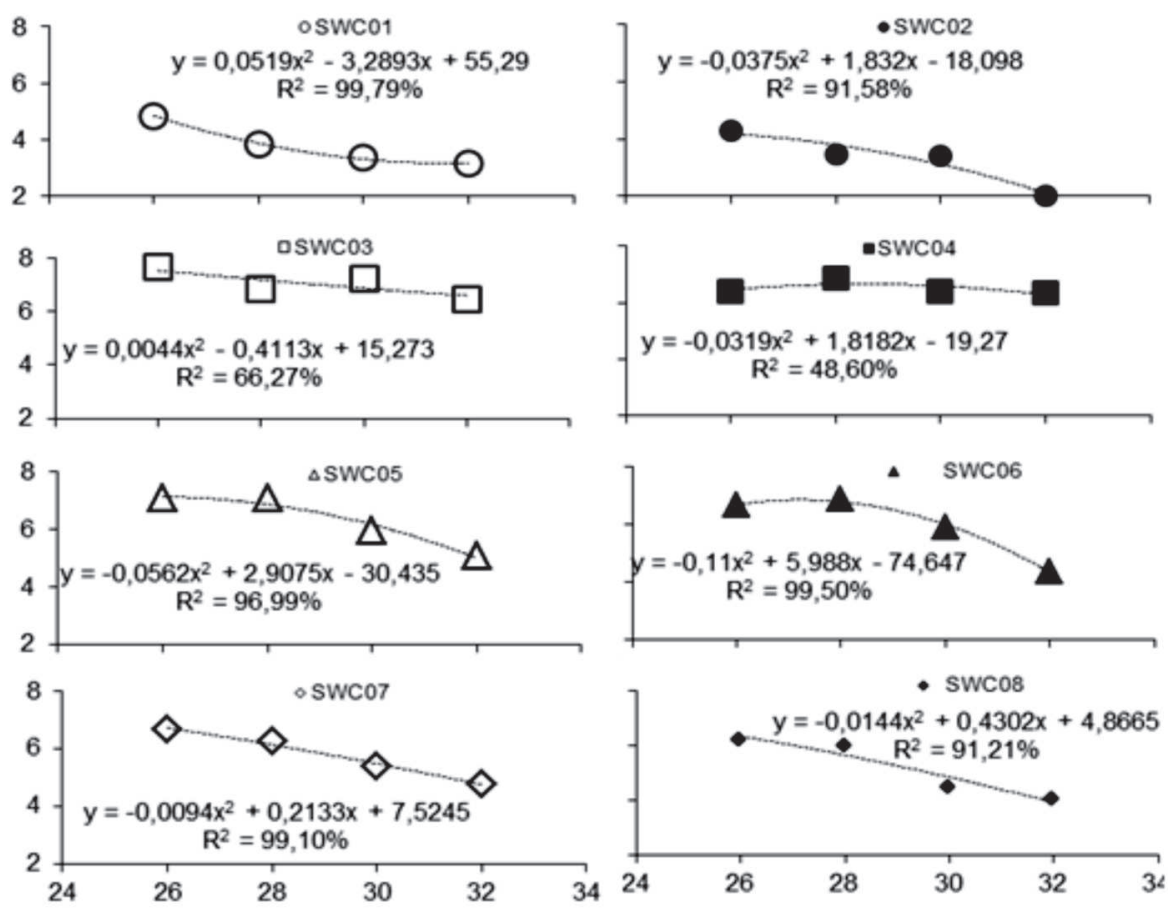

Dias após florescimento

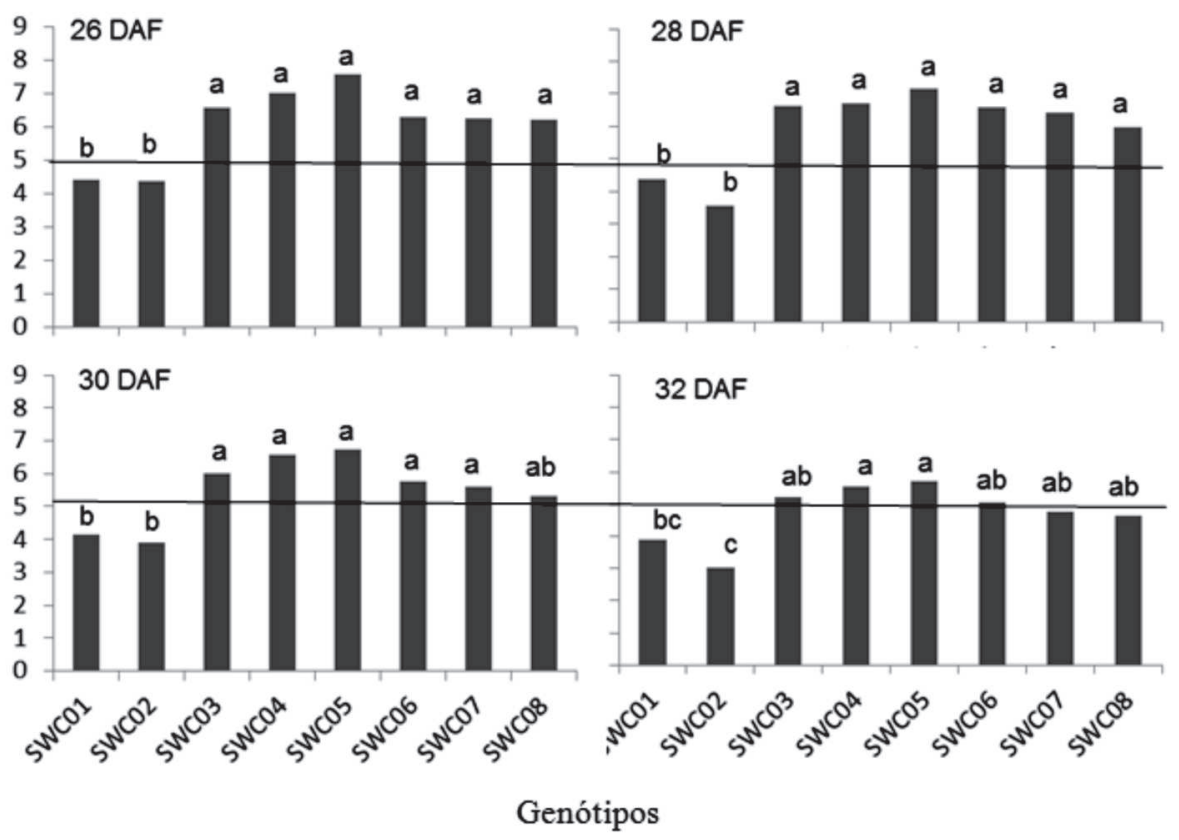

*avaliada em escala hedônica variando de 1:' desgostei extremamente' a 9:' gostei extremamente'

**Médias seguidas por letras iguais não apresentam diferenças significativas pelo teste de Tukey, a 5\% de significância.

Figura 2. Média de aceitação quanto à textura de híbridos de milho doce em função de intervalos de colheita. UFU, Uberlândia, 2010. 
Na última colheita (32 DAF), observou-se reflexo da atividade metabólica também nos híbridos de milho doce SWC 03, SWC 06, SWC 07 e SWC 08, o que gerou menor aceitação pelos participantes. A maioria dos híbridos de milho doce foi classificada como de sabor e textura indiferentes; já os híbridos SWC 04 e SWC 05, classificaram-se entre indiferente e de gosto ligeiramente bom.
A composição química dos grãos é o fator que define os atributos de qualidade e aceitação. As proporções de amido, polissacarídeos solúveis em água, açúcares redutores e sacarose, no milho, por sua vez, estão intimamente relacionadas com seu estádio de maturação (Caniato et al., 2004). Logo, o momento ideal de colheita reflete em máxima aceitação.
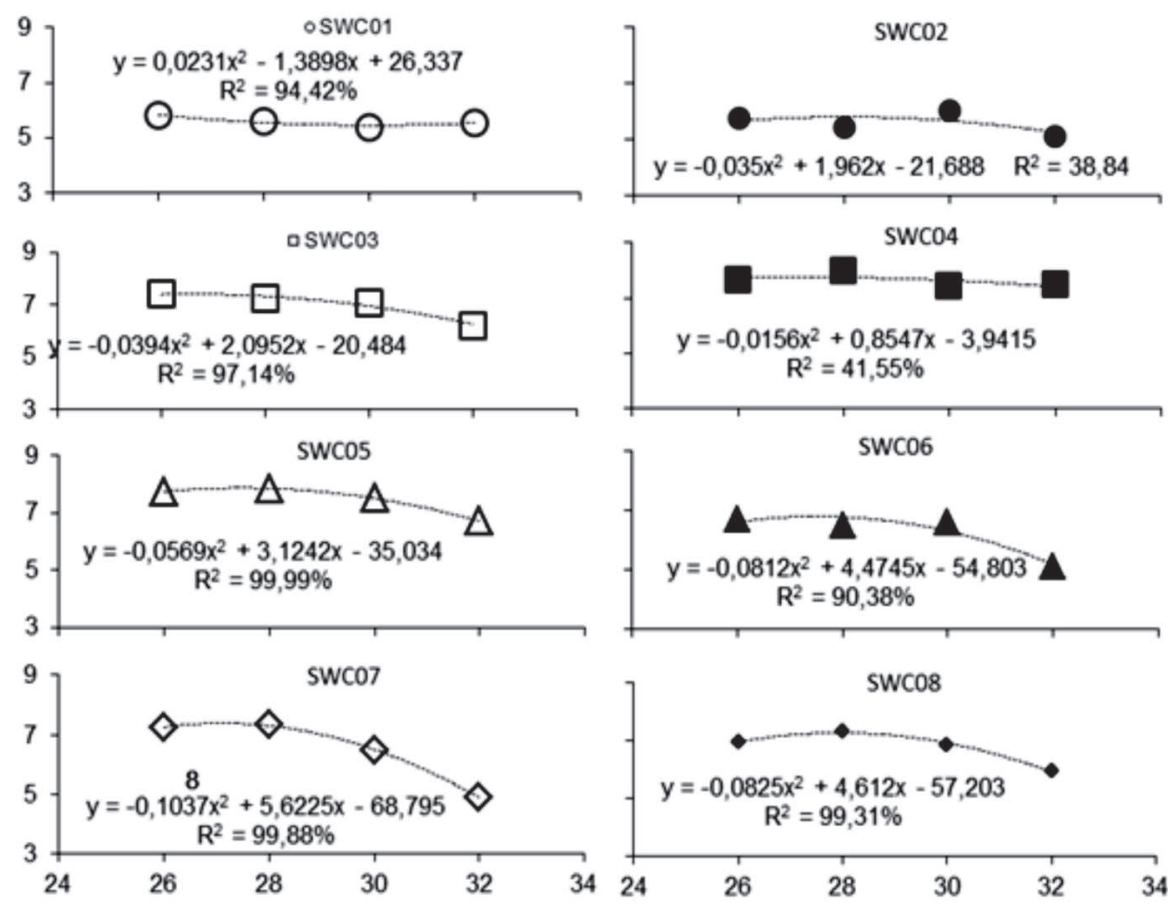

Dias após florescimento

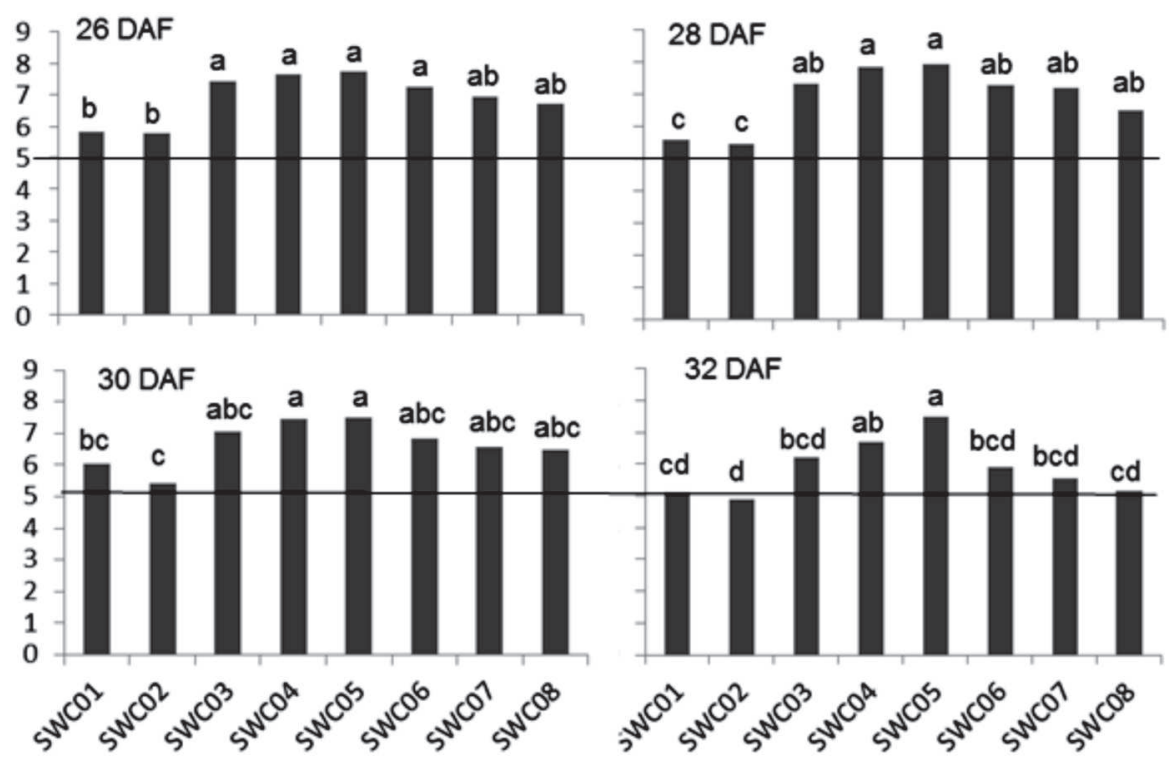

\section{Genótipos}

*avaliada em escala hedônica variando de 1:' desgostei extremamente' a 9:'gostei extremamente'

**Médias seguidas por letras iguais não apresentam diferenças significativas pelo teste de Tukey, a 5\% de significância.

Figura 3. Média de aceitação quanto à cor de híbridos de milho doce em função de intervalos de colheita. UFU, Uberlândia, 2010. 
Segundo Matos et al. (2000), é recomendável que a colheita seja realizada quando grande parte do amido não tenha sido acumulada, pois o sabor adocicado característico do produto fresco deve-se à presença de açúcares livres nos grãos. A perda da doçura nos grãos é devida à hidrólise de sacarose, que, no endosperma imaturo, é metabolizada para amido pela enzima sacaroseglucosil-transferase (Kwiatkowski \& Clemente, 2007). Neste trabalho, grãos colhidos aos 30 e 32 DAF, possivelmente, tinham maior taxa de conversão de sacarose em amido, o que reduziu a aceitação dos grãos dos híbridos pelos participantes.

É bom ressaltar que, apesar de o milho doce ter maior aceitação, ele pode perder até $14 \%$ do seu teor de açúcares, quando armazenado, a $20^{\circ} \mathrm{C}$, por um período de três horas. Essa perda pode ser reduzida a $4 \%$, em 24 horas e de 7 a $8 \%$, em 72 horas a $0{ }^{\circ} \mathrm{C}$ (Chitarra \& Chitarra, 2005). Logo, para garantia da qualidade e da aceitação dos materiais, o produto deve ser armazenado corretamente.

Observou-se que os provadores questionavam o sabor excessivamente adocicado de alguns híbridos de milho doce. Esta percepção pode ser comprovada por estudos de Tracy (2001), em que um híbrido de milho doce, da classe de endosperma superdoce, com o gene recessivo shrunken-2, apresentou $27,4 \%$ de sacarose, e um milho doce, da classe doce, com o gene recessivo sugary-1, apresentou teor de $11,6 \%$. Os alelos citados alteram a composição dos constituintes no endosperma e proporcionam acúmulo de açúcares.

Com essas vantagens, os híbridos de milho doce podem ser produzidos exclusivamente para venda para mercados distantes, o que reforça a oportunidade de exportação para o Brasil. De acordo com Barbieri et al. (2006), os Estados Unidos, Canadá e Europa são grandes consumidores de milho doce in natura, destacando-se como potenciais importadores do produto brasileiro.

Nos gráficos de regressão da Figura 2, observa-se que, para todos os híbridos avaliados, o melhor intervalo de colheita, quanto à aceitação de textura, foi entre os 26 e 28 DAF, sendo as menores médias de aceitação as das testemunhas (híbridos de milho verde, SWC01 e SWC02), que tiveram notas referentes a desgosto ligeiro a moderado. Para os híbridos de milho doce as notas variaram, entre os materiais genéticos, de gostei ligeiramente a gostei muito.

A partir desses resultados, é possível inferir que todos os híbridos experimentais foram geneticamente melhorados para textura, pois um programa de melhoramento deve visar também aos consumidores finais. Segundo Barbieri (2010), os consumidores brasileiros têm preferência por grãos de milho doce de coloração amarelo-clara, macio e adocicado.
Estudos de Tracy (2001), a respeito do efeito da maturidade em híbridos de milho doce, demonstraram que um híbrido de milho doce, colhido aos 16 DAF apresentou cerca de $23,3 \%$ de amido e, quando colhido aos $28 \mathrm{DAF}$, esta taxa subia para $35,4 \%$. Isso mostra que o bloqueio da conversão de açúcares em amido não é total e que qualquer atraso na colheita pode comprometer a qualidade dos grãos. Neste caso, o amido correlacionase diretamente com a textura dos grãos, pois, em virtude do arranjo das cadeias de amilose e amilopectina, o grão torna-se mais compacto e confere maior resistência à mastigação, resultando em textura desagradável para o consumidor (Tracy, 2001) .

A textura está diretamente relacionada com a espessura do pericarpo, que é uma característica de alta herdabilidade, isto é, tem baixo efeito do ambiente. Um pericarpo espesso também é responsável por conferir resistência à mastigação e a espessura do pericarpo é diretamente afetada pelo estádio de maturidade dos grãos, isto é, quanto mais maduro o grão, mais espesso é o pericarpo e menor é a aceitação da textura (Barbieri et al., 2006).

A aceitabilidade quanto à cor apresentou-se como o fator com menor variação entre os híbridos. Todos os híbridos apresentaram máxima aceitação também entre 26 e 28 DAF. Os híbridos de milho verde receberam notas de indiferente a gostei ligeiramente e os de milho doce a gostei moderadamente e gostei muito (Figura 3).

A partir da observação dos gráficos de barras da Figura 3, é possível visualizar que os híbridos SWC04 e SWC05 (ambos amarelo-claros brilhantes) apresentaram as maiores médias de aceitação, quanto à cor, em todos os intervalos de colheita, enquanto os híbridos SWC07 e SWC08, com colaração alaranjada, apresentaram as menores médias, porém sem diferença estatística para a maioria dos híbridos de milho doce (Figura 3).

O híbrido de milho doce que abastece mais de $80 \%$ do mercado brasileiro apresenta coloração amarelo-clara brilhante, o que comprova a preferência dos consumidores por milho de cor mais clara. Sabe-se que a coloração do endosperma do milho é controlada por um gene que confere cor amarela, quando homozigoto dominante, e cor branca, quando homozigoto recessivo. Por essa razão, para conseguir a coloração preferida pelo consumidor, uma das alternativas é lançar mão de algumas ferramentas do melhoramento genético de plantas, como o retrocruzamento (Barbieri et al., 2006).

A maior palatabilidade do milho doce atribui potencial para o cultivo como espécie hortícola, em virtude da agregação de valor em razão do alto preço unitário das espigas, a possibilidade de ser comercializada na forma miniprocessada e o aproveitamento da parte 
vegetativa, como feno ou silagem de alta qualidade. Empresas alimentícias, visando a oferecer um milho verde que satisfaça as exigências relacionadas com o paladar, estão trocando o milho verde, obtido do milho comum, pelo milho doce, incentivando os produtores com novos cultivares obtidos para o clima tropical (Kwiatkowski \& Clemente, 2007).

\section{CONCLUSÃO}

Os híbridos de milho doce têm maior aceitação sensorial que os híbridos de milho verde, independentemente do intervalo de colheita. Colheitas tardias (32 DAF) refletem-se em redução da aceitabilidade do milho doce, que se assemelham à aceitação do milho verde (entre indiferente e gostei ligeiramente, para cor, e desgostei ligeiramente e desgostei moderadamente, para textura e sabor).

Para todos os híbridos testados, a colheita, quando realizada entre 26 e 28 DAF, proporciona produtos com melhores resultados sensoriais (textura, sabor e cor).

\section{REFERÊNCIAS}

Aragão CA (2002) Avaliação de híbridos simples braquíticos de milho super doce (Zea mays L.) portadores do gene shrunken (sh2sh2) utilizando esquema dialélico parcial. Tese de Doutorado. Faculdade de Ciências Agronômicas, Botucatu. 101p.

Barbieri VHB, Luz JMQ, Brito CH, Duarte JM, Gomes LS \& Santana DG (2006) Produtividade e rendimento industrial de híbridos de milho doce em função de espaçamento e populações de plantas. Horticultura Brasileira, 23:826-830.

Barbieri VHB (2010) Mapeamento de QTL em testecrosses de milho doce com diferentes testadores e ambientes. Tese de Doutorado. Escola Superior de Agricultura "Luiz de Queiroz", Piracicaba. 130p.

Caniato FF, Galvão JCC, Finger FL, Ribeiro RA, Miranda GV \& Puiatti M (2004) Composição de açúcares solúveis totais, açúcares redutores e amido nos grãos verdes de cultivares de milho na colheita. Revista Brasileira de Milho e Sorgo, 3:38-44.

Chitarra MIF \& Chitarra AB (2005) Perdas pós-colheita. In: Chitarra MIF \& Chitarra AB (Eds.) Pós-colheita de frutas e hortaliças: fisiolo-

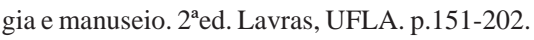

Courter JW, Rhodes AM, Garwood DL \& Mosely PR (1988) Classification of vegetables corns. HortScience, 23:449-450.

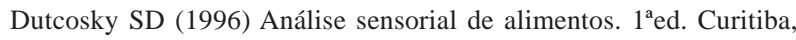
Champagnat. 83p.

Ferreira DF (2008) SISVAR: um programa para análises e ensino de estatística. Revista Symposium, 6:36-41.

Grigulo ASM, Azevedo VH, Krause W \& Azevedo PH (2011) Avaliação do desempenho de genótipos de milho para consumo in natura em Tangará da Serra, MT, Brasil. Bioscience Journal, 27:603-608.

Kwiatkowski A \& Clemente E (2007) Características do milho doce (Zea mays L.) para industrialização. Revista Brasileira de Tecnologia Agroindustrial, 1:93-103.

Matos MJLF, Tavares AS, Santos FF, Melo MF \& Lana MM (2000) Milho verde. Brasília, Correio Brasiliense. 3p. (Suplemento Especial).
Oliveira Junior LFG, Deliza R, Bressan-Smith R, Pereira MG \& Chiquiere TB (2006) Seleção de híbridos de milho mais promissores para o consumo in natura. Ciência de Tecnologia de Alimentos, 26:159-165.

Parentoni SN, Gama EEG, Magnavaca R, Reifschneider FB \& Villas Boas GL (1990) Milho Doce. Informe Agropecuário, 14:17-22.

Reis LS (2009) Desenvolvimento de genótipos de milho doce: avaliação de genitores e híbridos. Tese de Doutorado. Universidade Estadual do Norte Fluminense Darcy Ribeiro, Rio de Janeiro. 76p.

Tracy WF (2001) Sweet corn. In: Hallauer AR (Ed.) Specialty corn. $2^{\text {nd }}$ edition. Boca Raton, CRC Press. p.155-198.

Rev. Ceres, Viçosa, v. 62, n.1, p. 001-008, jan/fev, 2015 